\title{
Irrigation basins and cultivated land under the Twelfth Dynasty
}

Eric P. UPHILL

\begin{abstract}
This paper considers the extension of the irrigated land in the Nile valley. It discusses the similarity between the measurement of the riverine basin in the Sohag and Memphis area (about $10 \mathrm{~km}$ ) and the Egyptian unit of measurement, the iteru (itrw). This could have been the basis of the ancient irrigation structure of the Nile basin. Details from the White Chapel at Karnak are presented to support this idea in relation to recorded levels of water. This set of data, according to the author, is essential in understanding the irrigation system of ancient Egypt, which had already been constructed by the Middle Kingdom and whose origins can be traced back to the early Dynasties.

El presente trabajo considera la extensión del terreno irrigable en el valle del Nilo. Parte de la semejanza de la medida de la cuenca del río tomada en el area menfita y de Sohag, aproximadamente $10 \mathrm{~km}$, y su similitud con la medida de longitud fluvial, el iteru (itrw). La hipótesis del autor considera esta última medida como base de la estructura de irrigación del Egipto antiguo. En este contexto presenta las pruebas disponibles a partir de la información que aparece en la Capilla Blanca de Senuseret I en el templo de Karnak y su relación con la altura del agua medida en codos. Los datos aportados por este monumento son, para el autor, básicos para la comprensión del sistema de irrigación que en el Reino Medio ya estaba perfectamente estructurado y cuyos orígenes pueden rastrearse en las primeras dinastías.
\end{abstract}

KeY Words: Middle Kingdom, Senwseret I, White Chapel, irrigation

$\mathrm{T}$ he ancient basin system in use in Egypt until the construction of the first Aswan Dam is not only one of the wonders of the ancient and medieval worlds, but in sheer scale, conception and achievement one that far surpasses any others, or indeed perhaps all the seven canonical wonders combined. Both in its immense size and area, and also in its incredibly long period of existence as a working agricultural machine, it was unparalleled throughout the entire world until modern times.

Whilst looking for some possible clues as to its origin and its form of layout during the Pharaonic period, I was struck with the fact that some of the basins in the Sohag area and Memphite zone averaged approximately 10 $\mathrm{km}$ in length, or slightly more as recorded in plans and statistics of their length. This seemed to be analogous to $10.5 \mathrm{~km}$ and one ancient Egyptian riverine iteru (itrw) measure, which if so seemed an ideal unit to use in first laying out a hydraulic system. Given that the whole basin system in the Nile valley, and to some extent the Delta also, was arranged in a system of terraces or steps, often averaging about $1 \mathrm{~m}$ drop or 2 cubits, to allow for the descent of the Nile between Aswan and Cairo, this fact again seemed significant as suggesting that while a number of early tentative irrigation schemes for basins might have been constructed, a final or even entirely new scheme was first conceived at the time of the unification of Egypt or in the period soon after. When one government was in control of the Two Lands, it would command not only all the resources needed in both manpower and land resources i.e. tenure, but also have the political strength and hydraulic knowledge to effect this ambitious scheme. Given that the system has obviously been enlarged by the addition of new supplementary basins in the Nile valley as 


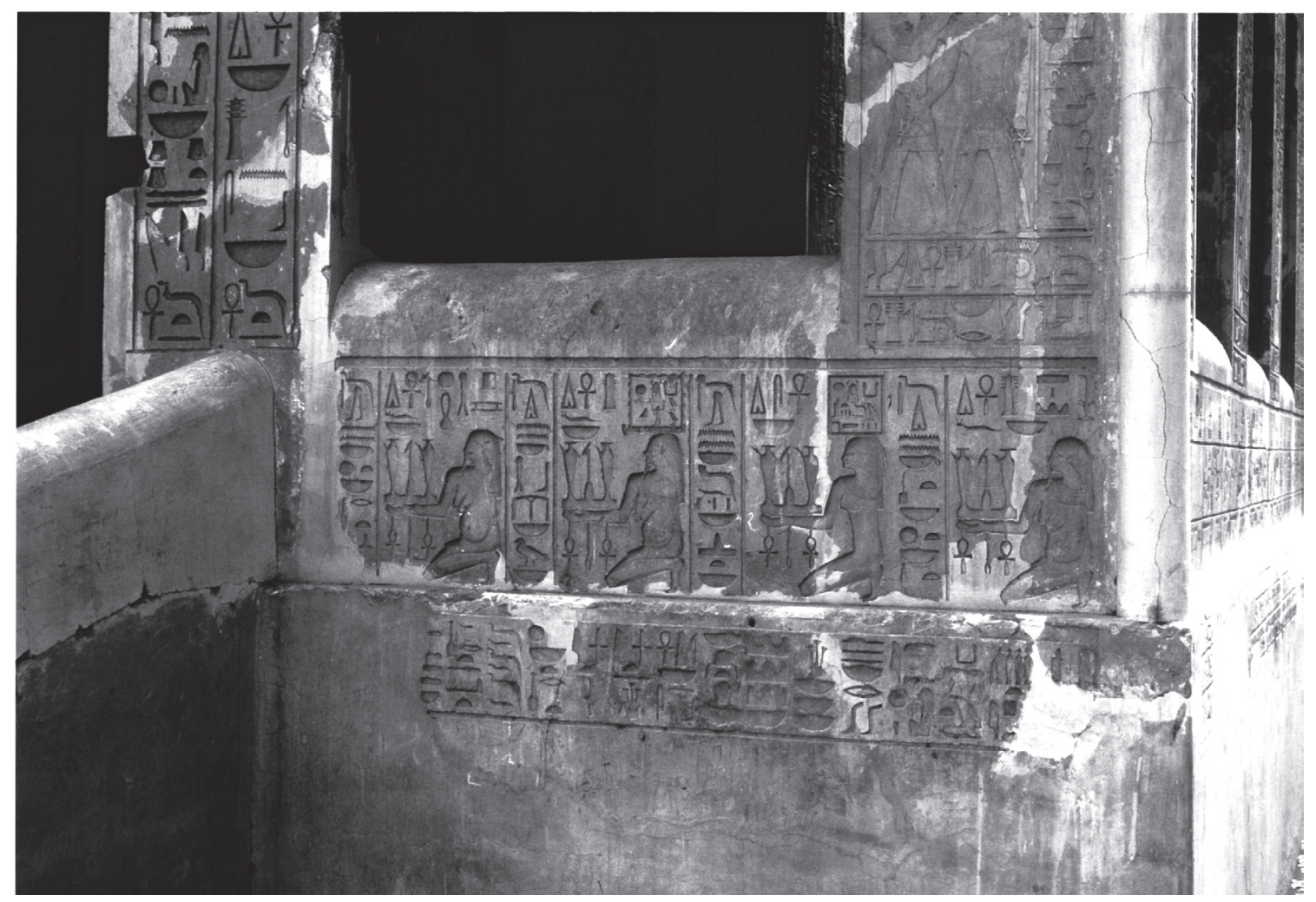

Figure 2. Line of kneeling Nile gods bearing trays with bread and jars of water on right (south) side of the west side of the stairway ramp.

more land was brought under cultivation, and these units were also adapted and basins subdivided as needed, these factors would have been obscured by later changes. Again the evidence cited below might suggest that only a narrow scheme running from the Aswan area to the central Delta coastal area formed the initial programme, but this initial scheme was expanded along all the other Nile branches in

[110 ] Lower Egypt by the beginning of the Twelfth Dynasty. Even allowing for neglect in times of weak or divided government and, as will be suggested, changes in physical climatic and geographical conditions during certain periods in history, the system could and did endure until recent times.

Another major factor in this quest for answers was the apparently standard length giv- en for the central Nile channel between Aswan and a point near the Delta coastline, cited on cubit rods down to the reign of Nectanebo II (359-341 BC) and at present first appearing in the cadastral survey figures recorded on the beautiful kiosk shrine of Senusret I erected on the occasion of his first Sed Festival in year 30/31 about $1930 \mathrm{BC}^{1}$. Therefore this system of measuring distances along the river between Abu (Elephantine) in the south and Per Hapi (Athat en Nabi at Cairo), followed by the distance from Per Hapi to Pehu Behdet or the marsh lands beyond modern Tell El-Balamun, became of critical importance. This great stretch of waterway was really the original central branch of the Nile channels through the Delta and, as I demonstrate, remained of great importance for at least fourteen centuries after Senusret I.

1. Lacau / Chévrier, 1956: 238-241. 
When erected, the Karnak Heb Sed Kiosk or "White Chapel" would probably have contained, as suggested by Lacau and Chévrier, two seated statues of the king, wearing the red and white crowns as shown in the Heb Sed scenes, which faced two approach ramps. In fact this $8 \mathrm{~m}^{2}$ monument is a permanent limestone equivalent of the temporary wood and matting baldachino pavilions used in the actual festival ceremonies. Hence the statues would have faced north and south so that the panels bearing the Upper Egyptian Nome scenes would be on the east side of the chapel and the Lower Egyptian ones on the west. This is rather analogous to the rows of shrines in the Heb Sed courtyard in the Step Pyramid complex at Saqqara which also show a logical interchange of north and south rows for the east and west sides.

The layout of the scenes is quite simple ${ }^{2}$ the sides with the ramps having sixteen Nile deities, four on the east and four on the west sides of the stairway ramps, arranged in procession, recalling many temple scenes of river gods bringing water and food (fig. 2). Elsewhere the texts refer to topographical features throughout Egypt, two natural (?) lakes, the sea, an artificial basin belonging to Amun, while among man-made items are four chapels and two fortresses built by Senusret I, these last being royal foundations as at Karnak itself.

The Karnak kiosk shrine is a little gem with superbly carved scenes but while these have been much discussed, the series of numerical survey figures on the lower parts of the exterior wall panels, and the square base podium below have not been subjected to such detailed analysis. Each column of inscriptions on the basement panels is divided into six rectangular divisions noted by Lacau and Chévrier to comprise (contain) from top to bottom the following ${ }^{3}$.

1. The Nome Names on the east and west sides listing Upper and Lower Egypt.

2. The name of the god and capital city of the Nome.

3. The area of the Nome lands in iteru measures thousands of cubit and stjat $(s \underline{t} 3 t)$ areas here, however, are denoted as simply odd hundreds over and above the previous figures.

4. Less certainly the word stjat used on its own.

5. What Lacau rendered as "what is cut off" (subtracted of the stjat $(100 \times 100$ cubits ?) postulated as the local stjat.

6. The remainder of the basement figures with the local value of the stjat (fig. 4). It is difficult to see what the last two explanations mean. Why should this standard measure of the land area vary from province to province?

The difficulties in interpreting and using these figures may explain why few published works have used this valuable material. Only Montet in his Géographie really made use of Lacau's published account and, while giving drawings and a general account, he does not offer a statistical breakdown of the areas of the cultivated lands inundated. Montet's figures are based on an extraordinary method of calculation using measures of length as areas or squares with each side of equal length, thus resulting in what can be shown to be a gross overestimate of the Twelfth Dynasty land areas. Thus instead of taking the iteru measures as simply lengths of 20000 cubits and the thousand totals as units of one twentieth of this, he again made them squares of the larger measure units, i.e. subdivisions of an iteru. These he set as $1 / 10$ : an impossible division

2. Lacau / Chévrier, 1956: pl. 2, for the east facade decorative layout.

3. Lacau / Chévrier, 1956: pl. 3, showing 20 panels containing the figures for the 22 Nomes of Upper Egypt, and pl. 42 with the 16 panels with figures of the 12 remaining Nome totals, the other panels on this façade contain general information about the Delta land lengths and inundation heights on cultivated land. 


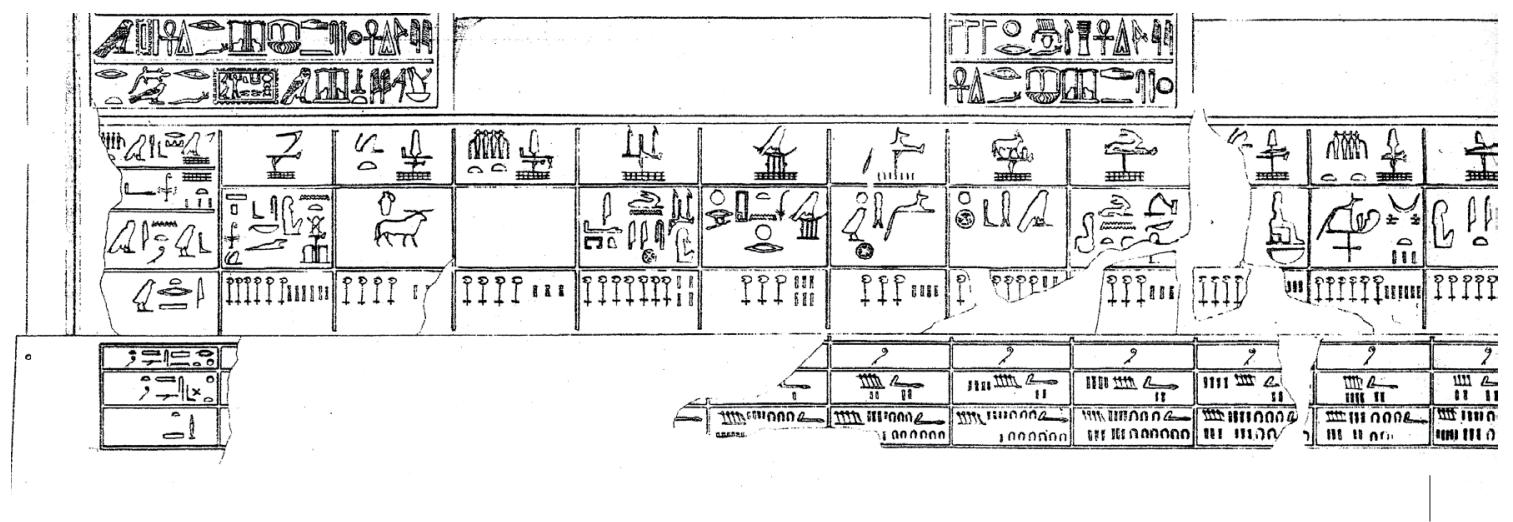

Figure 4 a (this page) $b$ (next page) Close up view of nine of the Southern Nome panels with four registers detailing figures of land areas and below on base platform Nile inundation heights.

as in real terms it would only be one four hundredth part of an area 1 iteru square, or $1 / 20$, if, as he implied, denoting a strip 1000 cubits wide. Whilst correctly noting the important point that the 86 iteru total for the Upper Egyptian nomes was not their actual length, but rather the length of their farm lands, he and others failed to note the critical point that this 86 measures is not the actual distance measured along the river channel, but falls about $42 \mathrm{~km}$ or 4 iteru short of the actual distance between Elephantine island and the southern area of Cairo. Such a discrepancy is not a minor miscalculation by the ancient surveyors. It represents a careful and accurate cartographical land measure of inundated field lands, not a general cadastral survey of Egyptian geography.

Montet's estimate of the length of these lands in Upper Egypt as 91 iteru is more accurate as will be shown: counting down the list totals [112] and including some lands probably in Nubia south of Aswan gives a total of around 95. In brief Montet's total for Upper Egypt was:

\begin{tabular}{ll}
91 iteru (i.e. squares) & $10032 \mathrm{~km}^{2} 750$ \\
87 thousands & $2379 \mathrm{~km}^{2} 450$ \\
17 aruras (stjat) & $46 \mathrm{~km}^{2} 695$ \\
\hline Total & $12448 \mathrm{~km}^{2} 895$ (sic)
\end{tabular}

In fact Montet's total here of 3112000 ha is an impossible one and the lower figure he gives elsewhere of 1244800 ha grossly exceeds the 2251000 acres under cultivation given by Willcocks (Egyptian Irrigation) in the $\mathrm{XIX}^{\text {th }}$ century AD.

The use of such abnormal renderings of iteru measures and thousand cubit units must render the land totals in some nome areas impossible. Upper Egyptian Nomes at the southern end could not have field areas of $10.5 \mathrm{~km}$ across east to west, although some in Middle Egypt might have reached this breadth. The narrow strips of land in the Nekhen area and north as far as the $5^{\text {th }}$ Nome will be shown to have cultivated land of not more than $1 / 10$ of this. Montet's assumption that the lands listed under Senusret I were about equal to those of modern Egypt is an astonishing over-estimate and the population will be shown to be less than in New Kingdom or Graeco-Roman Egypt.

Montet did not include a similar breakdown of land areas in his volume on Lower Egypt but appears to have allowed a similar ratio for them as for Upper Egypt in his estimate.

Using the leads provided above it is possible to begin to define what information the scribe who added these details intended to convey to the reader. Beginning with the over all length of the cited cultivated lands to which these statistics refer, the lengths are 


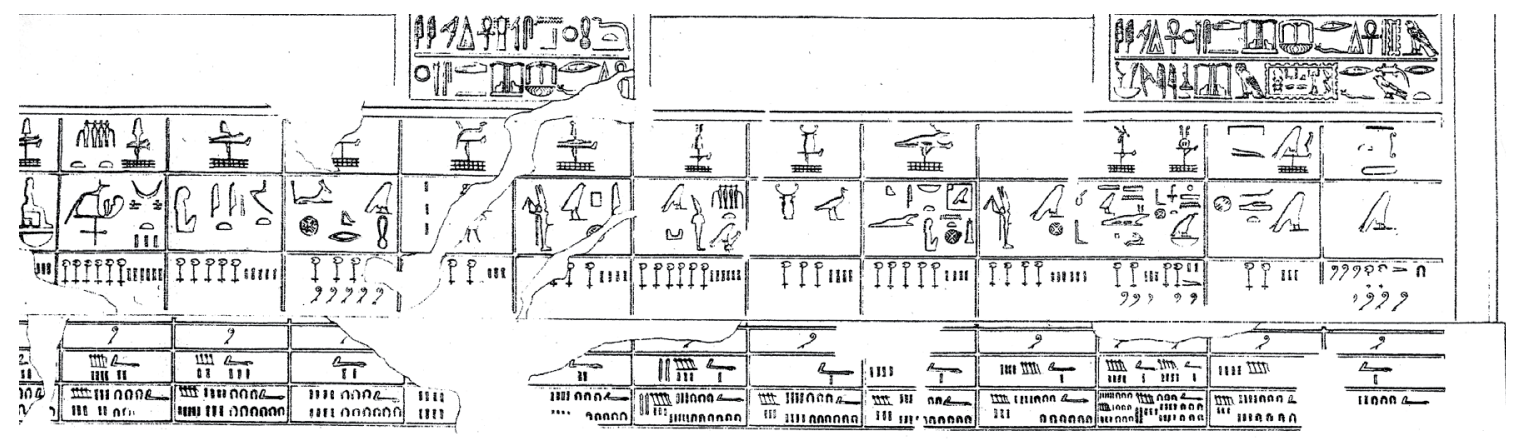

given as following a progression always from south to north ${ }^{4}$.

3bw hnt pr hpi 86 itrw. hnt pr hpi r phw bhdt 20. Total 106 itrw

This figure was often cited later on such items as the Nectanebo cubit rods, a damaged cubit measure of Osorkon in Cairo Museum, and an even more damaged cubit measure of Amenhotep III from the Tunah el-Gebel galleries ${ }^{5}$.

But the important fact about these distances is that on a standard iteru measure of 20 000 cubits 86 iteru would measure approximately $903 \mathrm{~km}$ yet the actual distance from Elephantine island to Athar en Nabi at Cairo is from figures cited by Willcocks ${ }^{6}$ and the Guide Bleu ${ }^{7}$ a river voyage length of around $942-943 \mathrm{~km}$. As shown this $40 \mathrm{~km}$ discrepancy can only be explained by the lesser total being related to field or inundated lands. The three places here mentioned are significantly linked with the inundation heights recorded on the kiosk.
Abu (Elephantine)

Per Hapi (Cairo area)

Pehu Behdet (Balamun) 6 cubits 3 palms 3 fingers

These heights varying between over $11 \mathrm{~m}$ and 3 to $4 \mathrm{~m}$ are as in modern times the total rise reached by the whole of the water in the actual Nile channel, in contrast to the next set of figures which give water on the adjoining fields ${ }^{8}$.

Inundation of the Nile on the (cultivated) lands between $\mathrm{Abu}$ and Per Hapi: 3 cubits 3 palms 3 fingers. After Per Hapi to Pehu Behdet: 4 cubits 3 fingers.

These figures represented in modern measurements approximately $1.605 \mathrm{~m}$ and $2.18 \mathrm{~m}$ and can be compared with those listed in Willcocks 9 . He indicated that the depth of water in small irrigation basins, after the dykes were cut, rose to a height of $30 \mathrm{~cm}$ on average, rising up to $3 \mathrm{~m}$ in very large basins, the average basin depth in the Nile valley being $1 \mathrm{~m}$. It is interesting to note that those in the Delta lands in the Twelfth Dynasty were flooded to

4. Montet, 1961: vol. 2, 10.

5. Lacau / Chévrier, 1956: 238-241.

6. Willcocks, 1889: 31 (table XI), and 57 (table XVI), i.e. a distance of $968 \mathrm{~km}$ minus the $23 \mathrm{~km}$ between the barrage and the Giza-Cairo basin, see also the pl. XII map of the Upper Egyptian basins not counting basin 77.

7. Guides bleus, 1950: 316, where the distance Cairo to Luxor is given as $722 \mathrm{~km}$, and 570 Luxor to Aswan as $218 \mathrm{~km}$ by river.

8. Lacau / Chévrier, 1956: 238-241.

9. Uphill, 1998: 1191-1195. 
a height of nearly 1 cubit more than those in the valley basins. Whether this had to do with greater sized basins or for some other reason is not at present clear.

These figures therefore represent the average or norm of the two stretches of the river as an analysis of the detailed information on the sequence of individual Nomes shows.

This statistical survey of each province's field water, i.e. basin, depths, and their areas of cultivated land, is therefore of critical importance to understanding and trying to establish a coherent and logical interpretation of what appears to be an invaluable cartographical survey register compiled four thousand years ago. The carvers who inscribed the figures on the kiosk side walls depicted the Nomes in a line running from right to left on the Upper Egyptian side and inversely left to right on the Lower Egyptian one. The first Upper Egyptian or most southern Nome is thus on the right (fig. 5) and the most northern twenty second one is found on the extreme left, while the first Lower Egyptian White Wall Nome is first at the left side of the Lower Egyptian row of provinces. Logically because of this the signs written in the Upper Egyptian register face right and thus read in order right to left with the highest numeral totals first, and viceversa for the Lower Egyptian sequence.

The compiler therefore used standard iteru riverine measures for the first larger dimension which in the Nile valley must have been the length of the tract of land, followed by units of one thousand cubits for the breadth, likewise for all the main land areas in Lower Egypt. Clearly tracts of fertile ground of more than 1 iteru measure across are impossible in the narrow Nile valley, most being less than one such measure, both then and today, and even in the Delta would be impossible to contrive where the five ancient Nile branches converged in the southern part. Since bends and the wind- ing of the river might preclude an exact fitting together of exactly rectangular land tracts, the scheme also allowed for extra smaller land areas to be assessed in hundreds as shown by the curl sign numerals, these residual pieces probably being located between or at the edges of the main zones or estates of fertile ground. In the table showing the main land areas of the Nomes, I have followed the suggestion of Lacau and taken these as denoting squares of one hundred cubits each way or 1 stjat of land. Had they denoted extra hundred cubits in the width of the tracts these would surely have been used more frequently than in only nine of a surviving thirty Nome details. If they did stand for slightly greater land widths this would still only add either 17000 or 18600 stjat or arura measures to Upper Egypt, and 13000 or 15000 to Lower Egypt, hence not greatly altering the sum totals.

These precise areas and regulated water heights presuppose a system based on hôd type basins as in later times, rather than an assessment denoting unenclosed stretches of fields. Possibly some other lands lay outside the basins enclosed by dykes and were not included in this survey of what may be termed Royal or State administered lands under government control.

In support of this method of reading the kiosk statistics as opposed to that used by Montet, two examples of how land areas were normally measured and recorded will suffice to show the method. In the Fifth Dynasty the royal minister Senedjemib records the making of a garden or lake called "Lotus Blossom of Isesi" (king Djedkare') measuring $1200 \times 440$ cubits or about $640 \mathrm{~m} \times 231 \mathrm{~m}$ and is an early example of the standard method of giving length by width. The much greater and more famous lake made by king Amenhotep III for queen Tiy, measured from the details recorded on the commemorative scarab 3700 cubits long by 700 cubits wide around $1942.5 \mathrm{~m} \times 367.5 \mathrm{~m}$. 

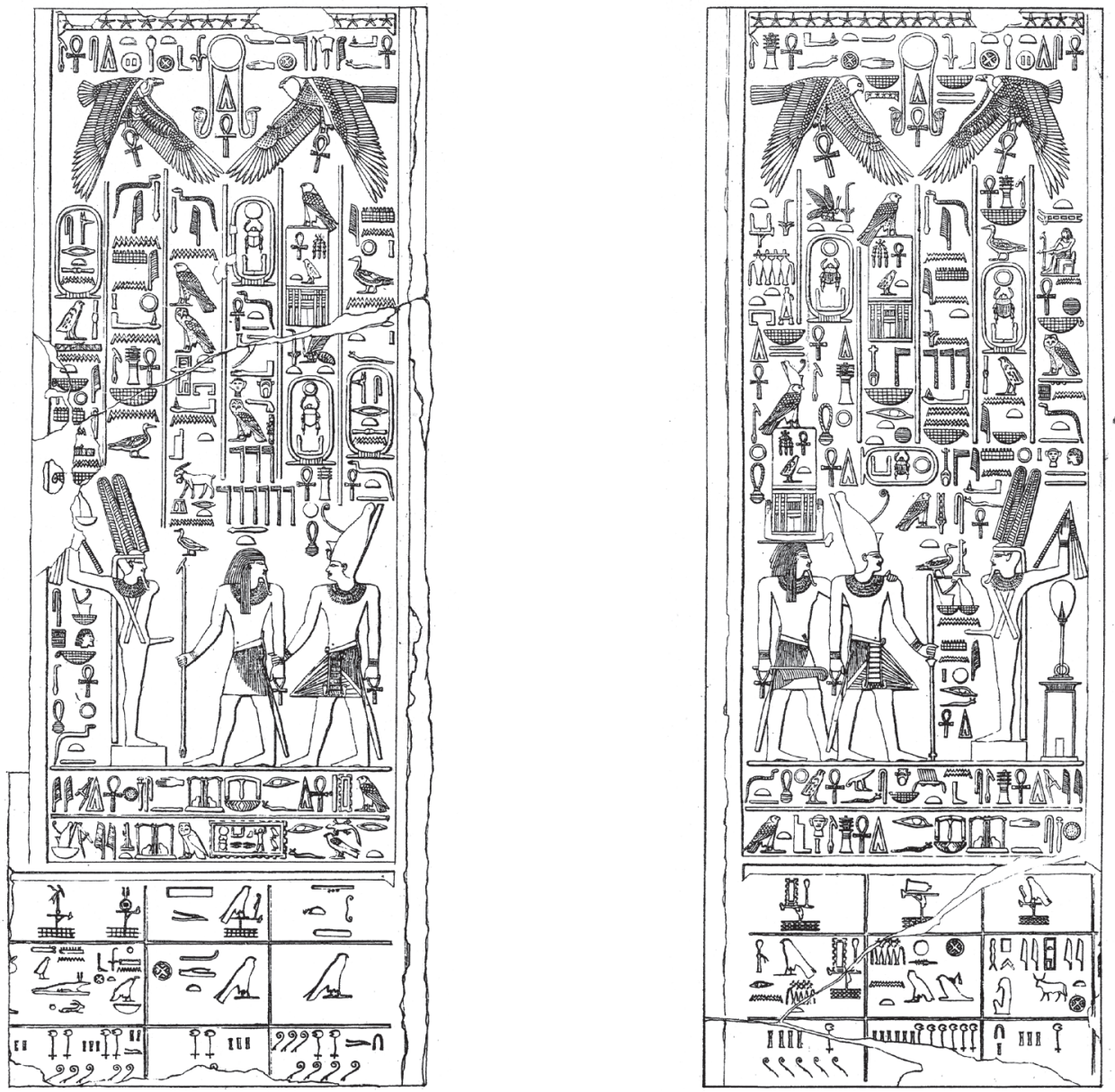

Figure 5. Close up of the south east corner of the kiosk with above scene of Senusret I wearing the double crown being led into the presence of Amun Kamutef, and below a reference to the Heb Sed ceremonies in the fortified Residence at Thebes, and details of the land areas of the four most southern Upper Egyptian Nomes.

An exception to the rule is the figure given for the king's land grant made by Akhenaten for the new city of Akhetaten. The boundary stelae located at different points on the rocks surrounding the cartouche-shaped city zone, and sited well beyond the actual rectangular land tract intended to supply food for the inhabitants, do not give the distance as measured between one stela and another on east and west banks, but in fact the land circuit, hence the distance is standard from whichever stela it is taken. The topography shows that the land periphery is as the stelae state approximately $1 \frac{3}{4}$ iteru east west by $1 \frac{1 / 4}{4}$ north south or just over 6 iteru this reaching $63 \mathrm{~km}$. This tract must have cut across the existing basin system here and if so $^{10}$ did not necessarily follow the dykes enclosing the basins.

Using the method of reading given above the following system of land assessment can be reconstructed, allowing that this interpretation, while being a reliable means of ascertaining the approximate figures from which the scribe worked, is subject to some uncertainty owing to missing or only partly preserved figures.

10. Lacau / Chévrier, 1969: pl. 25 (scenes 27’ \& 28'), pl. 3 (scenes 28 \& 27), pl. 26 (scenes 30 \& 29, 29’ \& 30'). 
The Delta Nome topography is also by its nature much less clear at times than that of the valley.

The land areas for Upper Egypt will be seen to follow a consistent picture of increasing width, from the narrow southern Nomes in the Nekhen area as far as the much wider ones in the Fayum area, and then the more restricted ones in the Memphis zone. In general, save for a few discrepancies, these land area figures are fairly clear and fit the topography well, unlike those of Lower Egypt, where apart from the loss of four sets of Nome details, certain problems arise in regard to some Nome statistics. Special cases where these occur as in the Eighth Nome, will be discussed later and some possible explanations given as to the anomalies. Bearing these factors in mind the following breakdown presents the most probable interpretation ${ }^{11}$.

\section{UPPER EGYPTIAN NOMES}

\begin{tabular}{|c|c|c|c|c|c|c|c|}
\hline 1. & Ta Seti. Nubia & 10 & iteru* & 2000 & cubits & $300+400$ & stjat. \\
\hline 2. & Apollinopolis Magna & 3 & « & 2000 & « & & \\
\hline 3. & Eileithyiapolis & 2 & « & 2000 & « & $200-300 ?$ & « \\
\hline 4. & Diospolis Magna & 3 & « & 2000 & « & 200-300 & « \\
\hline 5. & Gebtiu (Coptos) & 6 & « & 4000 & « & & \\
\hline 6. & Tentyris (Dendera) & 4 & « & 5000 & « & & \\
\hline 7. & Diospolis Parva $(\mathrm{Hu})$ & 4 & « & 3000 & $«$ & & \\
\hline 8. & Thinis (Ta Wer) & 6 & « & 6000 & « & & \\
\hline 9. & Panopolis (Khem) & 4 & « & $2000-3000$ & « & & \\
\hline 10. & Wadjet & 3 & « & $2000+$ & $«$ & & \\
\hline 11. & Hypselis & $5 ?$ & « & 3000 & $«$ & & \\
\hline 12. & Dju-ef & 5 & « & 5000 & $«$ & & \\
\hline 13. & Atef Khentet & 6 & « & 6000 & « & & \\
\hline 14. & Atef Pehut & 3 & « & $4000+?$ & $«$ & & \\
\hline 15. & Wenen & 3 & « & $3000+$ & $«$ & & \\
\hline 16. & Ma-Hedj & 3 & « & $6000+$ & $«$ & & \\
\hline 17. & Inpu & 4 & « & 3000 & $«$ & & \\
\hline 18. & Sepa & 6 & « & 3000 & « & & \\
\hline 19. & Wabu & 4 & « & 7000 & $«$ & & \\
\hline 20. & Nar-t Khentet & 3 & « & 4000 & $«$ & & \\
\hline 21. & Nar-t Pehut & 3 & « & 4000 & « & & \\
\hline 22. & Knife & 6 & « & 6000 & « & & \\
\hline
\end{tabular}

* This length of around $105 \mathrm{~km}$ is impossible for the actual Nome as far as Aswan which measured around 22 $\mathrm{km}$ to the next Nome border, and may have included part of or even all the cultivated lands south of Abu in Nubia proper at this time. Likewise there may have a third hundred sign between the two stjat totals under Nomes 3 and 4, as remaining the higher total is nearer to the Nome 4 spacing. Nomes marked with a + may also have had up to 1000 more cubits width. 


\begin{tabular}{|c|c|c|c|c|c|c|c|}
\hline 1. & Inb Hedj & 4 & iteru & 1000 & cubits. & 500 & stjat. \\
\hline 2. & Duau & 5 & « & 6000 & « & & \\
\hline 3. & Imen (West) & $11+3$ & $\ll$ & 1000 & « & & \\
\hline 4. & Sapi Shema (Prosopis) & 5 & $\ll$ & 1000 & « & & \\
\hline 5. & Sapi Meht (Sai) & $5^{*}$ & $«$ & 1000 & « & & \\
\hline \multirow[t]{3}{*}{6.} & Ka Khaset & 10 or 12 & $«$ & 7000 & « & & \\
\hline & & 4 or 2 & $«$ & & & & \\
\hline & & $\overline{14}$ & $«$ & & & & \\
\hline 7. & Nefer Imenti & 5 & $\ll$ & 700 & « & & \\
\hline \multirow[t]{3}{*}{8.} & Nefer Iabti & 4 & $«$ & 6000 & « & & \\
\hline & & 4 & $«$ & 3000 & « & & \\
\hline & & $\overline{8}$ & « & & & & \\
\hline \multirow[t]{2}{*}{9.} & Andjty & 13 & « & 1000 & « & 50 & « \\
\hline & Details on missing block & omes $10-1$ & & & & & \\
\hline 14. & Kenet Iabti & 12 & $«$ & 6000 & « & 300 & « \\
\hline 15. & Djehuty & 13 or 15 & « & 3000 & $«$ & 500 & « \\
\hline 16. & Silure (Fish) & 3 & $«$ & 2000 & $«$ & & \\
\hline
\end{tabular}

* or 0 iteru if the previous 5 include this Nomes totals.

These figures show that five Lower Egyptian Nomes contained far greater lengths of land tracts than any in Upper Egypt except Nubia. It is significant that Djani (Tanis), the Fourteenth Nome of Lower Egypt, was sited in one of the two most land- rich Delta Nomes just west of Per Ramesses, the royal es- tate, whose west side extends into it.

The kiosk also provides figures of the height of the flood water in each Nome. In general they are similar in various sectors - such as those in the southern Nile valley as opposed to those further north or in the Delta.

\begin{tabular}{lll}
\multicolumn{2}{l}{ Upper Egypt } \\
\hline \hline Nome & & \\
1. & 1 cubit & $*$ \\
2. & missing & 4 palms \\
3. & 1 cubit & 4 palms \\
4. & 1 cubit & 4 palms \\
5. & 1 cubit & 4 palms \\
6. & 1 cubit & 4 palms \\
7. & 1 cubit & missing \\
8. & 1 cubit & 3 palms \\
9. & 2 cubits & missing \\
10. & missing & missing \\
11. & 2 cubits & \\
\hline
\end{tabular}

\begin{tabular}{lll}
\hline \hline Nome & & \\
12. & 3 cubits & 2 palms \\
13. & 2 cubits & 4 palms \\
14. & 2 cubits & 4 palms \\
15. & 2 cubits & 4 palms \\
16. & 2 cubits & 4 palms \\
17. & 2 cubits & 2 palms \\
18. & 1 cubit & missing \\
19. & missing & missing \\
20. & missing & missing \\
21. & missing & missing \\
22. & missing & missing \\
\hline \hline
\end{tabular}

* No shorter measures listed perhaps rounded up 
Lower Egypt

\begin{tabular}{llll}
\hline \hline Nome & & & \\
1. & missing & $31 \frac{1}{2}$ palms & \\
2. & 1 cubit & 4 palms & \\
3. & 1 cubit & 4 palms & 2 fingers \\
4. & 1 cubit & 5 palms & \\
5. & 1 cubit & 5 palms & \\
6. & 1 cubit & 5 palms & \\
7. & 1 cubit & 3 palms & \\
8. & 1 cubit & missing & \\
9. & 2 cubits & 3 palms & \\
$10 ?$ & 1 cubit & 5 palms & \\
$11 ?$ & 1 cubit & 4 palms & \\
$12 ?$ & 1 cubit & 3 palms & 13 fingers* \\
$13 ?$ & 2 cubits & 3 palms & 2 fingers \\
14. & 2 cubits & 3 palms & 2 fingers \\
15. & $1+?$ cubit & missing & 2 fingers \\
16. & 1 cubit & 3 palms & 2 fingers \\
\hline \hline
\end{tabular}

* i.e. 3 parts (of a finger)

The relative areas of the Nomes in the four missing name panels is not certain. In fifteen Upper Egyptian provinces those as far north as the seventh Nome had 1 cubit plus some palms and fingers water height, but seven from the eighth to seventeenth Nomes had at least 2 cubits plus some palms and fingers, while the $12^{\text {th }}$ Nome reached an exceptional 3 cubits 4 palms 2 fingers. To the north Nome 18 only reached 1 cubit, but possibly as the remaining palms and fingers are missing this should read as originally 2 cubits plus some palms and fingers. As the remaining northern valley Nome [118] details are lost it is unclear whether they followed the southern or central zone height patterns. In general the figures indicate lesser heights in the extreme south, where the actual inundation waters in the Nile channel would have been at their greatest level, but also flowing fast to the north. These were followed by larger areas flooded to greater heights in the areas of greater basins from the Thinite Nome northwards at least as far as the $18^{\text {th }}$ Nome. It should be noted that only the $12^{\text {th }}$ Nome fig- ures equal the height recorded for the overall height between Abu and Per Hapi.

For Lower Egypt the remaining figures from the eleven surviving of the original sixteen are all of comparable heights to those in Upper Egypt. The 1st Nome or White Wall province being still in the valley only preserves the palm and finger heights, but the next seven listed all reach 1 cubit plus some palms and fingers, and are thus comparable with those in the south of the valley. In contrast the $9^{\text {th }}$ Nome (Busiris) reached 2 cubits and some palms. The next three panels representing uncertain Nome locations revert to only 1 cubit plus palms and fingers. In general this might suggest that the Delta had somewhat lower levels in the basins than in the central zone ones of the valley. This may possibly be owing to their situation on the periphery of the Delta flood plain, with perhaps a number like the $9^{\text {th }}$ Nome being in the central and more southern areas reached by higher levels of flood waters at the point where the Nile bifurcated. This phenomenon may also explain the apparent anomaly of the higher level of the listed figures over all field water or it may represent an increase of flood water in the channel of the main river branch between Per Hapi and Pehu Behdet as compared with that between Per Hapi and Abu in the south. Its 4 cubits 3 fingers may possibly relate to the main channel overflow factor with its passage through the lands immediately east of the $9^{\text {th }}$ Nome, also indicating the route of the greatest volume of Nile water flowing to the sea four thousand years ago.

Such evidence if correctly interpreted may explain why the river route between Aswan and the sea coast just beyond Tell El-Balamun became of major importance from a period before Senusret I until at least the end of the Thirtieth Dynasty.

So far as concerns the linear distance between these points, it has already been shown 
that the cited length of 86 iteru falls short of the actual distance between Abu and Per Hapi by as much as 4 iteru or approximately $42 \mathrm{~km}$ : the distance from Cairo southward of the main basin system in the Nile valley. There were only two small basins on the east and west banks in the stretch between Silsileh and Elephantine that may or may not have dated back to ancient times. There were also some small gaps in the basin system in the stretch north of Silsileh to the area just north of Luxor and Dendera, so that the actual lengths of the basins from north to south reached $852 \mathrm{~km}$ as far as Cairo. The lengths of the inundated lands in the Senusret figures from south to north aggregate excluding the 10 iteru of the Nubian Nome, a probable 85-86 iteru as shown above.

The shorter stretch of 20 iteru between Per Hapi and Pehu Behdet equates more accurately with the actual distance along the river channel which, while not quite the same as the Tanitic one today, would probably be in the region of the $210 \mathrm{~km}$ implied.

Some issues remain unclear given the information recorded on the kiosk which is currently available, such as the question as to whether there was more than one set of basins in the valley placed side by side east to west, as shown in the modern record of the system at least with regard to the zone south of the Fayum entrance channel, and that contiguous with the zone served by the Bahr Yusef canal. Perhaps initially, when the valley system was installed fully, there was only a single chain of basins on one side or perhaps both sides in the wider areas, which was later enlarged with parallel basins in the wider tracts of fertile ground.

The following table gives details and totals of the estimated land areas under Senusret I.

Allowing an average area for the missing Delta Nome totals based on the aggregate of the surviving twelve, the Lower Egyptian land area would be increased by one third to an approximate figure of between 896730 stjat or 912730 stjat. The combined total of cultivated land was therefore between 452166 ha and 458879 ha in modern measures or 1637 030 to 1669030 stjat. The combined total of cultivated land was therefore between 452166 ha and 458879 ha in modern measures or 1 637030 to 1669030 stjat. This figure when compared with the total land grants of Ramesses III listed in Papyrus Harris reaching 1 071780 stjat or around 295368 ha or nearly two thirds. Previous estimates suggesting that the Harris figures represent only one eighth or even tenth of the total cultivated land then existing in Egypt, or even the empire as a whole, may be an over- estimate of these lands if based on figures of around 8500000 to 10 720000 stjat, the latter being five times the Senusret chapel total set out here.

Two apparently anomalous sets of figures occur in the Twelfth Dynasty Nome statistics, those of the first Upper Egyptian or Nubian Nome, and the two sets of measurements listed for the sixth and eighth Lower Egyptian ones. The sixth Nome appears to contain two separate length totals reading as either 10 and 4 or 12 and 2 iteru lengths, both having a total of 14 measures and both of equal width at 7000 cubits. This may indicate two tracts of land on either side of one of the Nile branches, or possibly a longer and shorter length calculated to allow for a widening area between two Nile channels at the north end. Without more information on the ancient topography in this part of the Delta it is impossible to locate the sequence as in the Upper Egyptian Nomes.

The eighth Nome is divided into two tracts of equal length or 4 iteru, but with one of them being only half the width of the other or 3000 as opposed to 6000 cubits. Significantly this Nome is the one containing the Wadi Tumilat, and the figures may therefore refer to two possible land divisions depending on how far the cultivated land then existed along the Wadi. 
Breakdown of Reconstructed Basin and Land Sizes Senusret I

Upper Egypt and Nubia

\begin{tabular}{|c|c|c|c|c|}
\hline Nome & Length in iteru & Breadth in Cubits & Additional stjat & Area \\
\hline 1. & 10 & 2000 & $300+400 ?$ & 40700 stjat \\
\hline 2. & 3 & 2000 & & 12000 \\
\hline 3. & 2 & 2000 & 200 & 8200 \\
\hline 4. & 3 & 2000 & $200-300$ & $12300 ?$ \\
\hline 5. & 6 & 4000 & & 48000 \\
\hline 6. & 4 & 5000 & & 40000 \\
\hline 7. & 4 & 3000 & & 24000 \\
\hline 8. & 6 & 6000 & & 72000 \\
\hline 9. & 4 & $2000-3000$ & & $16000-24000$ \\
\hline 10. & 3 & 2000 or more & & 12000 \\
\hline 11. & $5 ?$ & $3000 ?$ & $300 ?$ & $30300 ?$ \\
\hline 12. & 5 & 5000 & & 50000 \\
\hline 13. & 6 & 6000 & & 72000 \\
\hline 14. & 3 & $4000+?$ & & $24000+$ \\
\hline 15. & 3 & 3000 or more & & $18000+$ \\
\hline 16. & 3 & 6000 or more & & $36000+$ \\
\hline 17. & 4 & 3000 & & 24000 \\
\hline 18. & 6 & 3000 & & 36000 \\
\hline 19. & 4 & 7000 & & 56000 \\
\hline 20. & 3 & 4000 & & 24000 \\
\hline 21. & $2-3$ & 4000 & & $16000-24000$ \\
\hline 22. & 6 & 6000 & & 72000 \\
\hline Total & $95-96$ & & $1000-1700$ & $740500-756700$ \\
\hline \multicolumn{5}{|c|}{ Lower Egypt } \\
\hline 1. & 4 & 1000 & 500 & 8500 \\
\hline 2. & 5 & 6000 & & 60000 \\
\hline 3. & $11+3$ & 1000 & & 28000 \\
\hline 4. & 5 & 1000 & & 10000 \\
\hline 5. & 5 or less? & 1000 & & 10000 or less \\
\hline 6. & 14 & 7000 & & 196000 \\
\hline 7. & 5 & 700 & & 7000 \\
\hline \multirow[t]{2}{*}{8.} & 4 & 6000 & & 48000 \\
\hline & 4 & 3000 & & 24000 \\
\hline 9. & 13 & 1000 & 50 & 26050 \\
\hline 10. & missing & & & \\
\hline 11. & missing & & & \\
\hline 12. & missing & & & \\
\hline 13. & missing & & & \\
\hline 14. & 12 & 6000 & 300 & 143300 \\
\hline 15. & 13 or 15 & 3000 & 500 & 78500 or 90500 \\
\hline 16. & 3 & 2000 & & 12000 \\
\hline \multicolumn{2}{|c|}{ Total for 12 Nomes Lower Egypt } & & 1.350 & 672350 or 684350 \\
\hline & Total for Egypt & & $2350-3050$ & 1412850 or 1441050 \\
\hline
\end{tabular}


If the wider $42 \mathrm{~km}$ long belt of land represented the western half of the Nome reaching from the Pelusiac branch of the Nile as far as the Nome capital Per Atum of Tcheku or Hierakonpolis (Tell er Retabeh rather than as once thought Tell el Maskhutah), then the present day zone of cultivated ground fits such a $3 \mathrm{~km}$ wide tract of fertile ground very closely. The remaining stretch along the Wadi of roughly equal length as far as Lake Timsah or the ancient Kem Wer lake is also much narrower and does not exceed $1.5 \mathrm{~km}$ at any point. An interesting story cited in the Natural History of Pliny in reference to the Nile-Red Sea canal of Necho and Darius, states that the 62.5 Roman miles long project was originally conceived by Sesostris. Slightly earlier Strabo in his account of this major project, added important information to the account in his statement that it also flowed through the Bitter Lakes, as they were called in his own day. These had ceased to be so when the canal was cut: they changed because their waters were diluted with that of the river, and so became fresh reservoirs, wellsupplied with fish and full of aquatic birds. Strabo also dates it to Sesostris and thus before de Trojan War though some ascribed it to Necho. Surveys of the courses of two canals apparently those of Darius and the narrower one of Ptolemy show they bifurcated apparently from the Wadi Tumilat just before reaching the Suez area. If so there was an essential difference between them and the putative earlier canal, the former having a maritime use while the latter one being for irrigation purposes. Whilst one should be cautious of attaching too much significance to the link with the legendary Sesostris or Senusret, it is perhaps relevant that in the Instruction to Merikare the Tenth Dynasty king is advised by his father to construct a canal as far as Kem Wer.

The interpretation of the figures for the $\mathrm{Nu}$ bian Nome and how its lands were measured is more complicated. Two possible explanations can be postulated, allowing for the fact that most if not all its lands were located south of Aswan. The first takes the total as including all the lands cultivatable in the barren stretch as far as the southern boundary of Egyptian control at Semna South fort, a distance of approximately $420 \mathrm{~km}$ or 40 iteru south of the First Cataract. This would mean that this great distance was divided into four equal zones of 10 iteru each and their cultivated lands assessed in strips only 500 cubits or $260 \mathrm{~m}$ wide, perhaps to fit the very narrow valley in the area immediately south of the First Cataract. Further south in areas like that opposite Buhen and Wadi Halfa there was a wider stretch up to perhaps $1 \mathrm{~km}$ or more running for some distance northward. This situation would fit the lands existing up to the time of the erection of the first Aswan dam.

The second explanation allows for a literal acceptance of the 10 iteru length but also including the 2000 cubits, so that the smaller figures in hundreds would not represent squares or stjat areas but literally two narrow strips of land of 300 cubits $(158 \mathrm{~m})$ and 400 cubits $(210$ $\mathrm{m})$ along either river bank. This would agree with the land grant cited in the Sehel island inscription given by king Djoser in the Third Dynasty to the god Khnum of Elephantine, that included all the cultivated land on either bank for a distance of 12 iteru south of Elephantine as far as Takompso. Against this interpretation is the problem that, as shown in the rest of the analysis, the thousand measures only fit the tract widths in the rest of the Nome statistics and while the odd hundreds could represent additional width figures in the other seven Nomes totals where they appear, these areas would not greatly alter the totals suggested in the table.

The first explanation therefore seems more probable. Willcocks ${ }^{12}$ noted that the mean width of the Nile in his time between Wadi Halfa and Aswan was $550 \mathrm{~m}$ and the mean depths in flood and in summer varied between

12. Willcocks, 1889: 8-9. Also noted that the mean width of the Nile in summer between Khartoum and Cairo was $300 \mathrm{~m}$. 
$9 \mathrm{~m}$ and $7 \mathrm{~m}$. This meant that a large expanse of land would be laid bare or drained of water annually. He also noted the existence at that time of a series of gigantic stone spurs or partial dams on both banks, that without fully blocking the main river flow, had the effect of partially blocking and holding back the flood waters. He suggested that "their function was collecting soil on both sides in flood and training the river in summer". The implication of this is that they would create valuable alluvium deposits and thus extend existing agricultural land. He dated some of the largest of the spurs to Ramesses II due to their proximity to settlements such as Gerf Hussein ${ }^{13}$. But this was written at a time when the existence and function of the great Twelfth Dynasty chain of fortresses was only just beginning to be known, hence many implications about their food supply would not have been considered. It is very significant that a number of these spurs are in the area of these fortresses, possible examples being at Aniba and Buhen, a Nile height recorded at a former indicating that a flood under Senusret II reached to some way above the level in the 1930s at the time of excavation work here.

These great stone barriers were also discussed by Vercoutter ${ }^{14}$ who noted their resemblance to other partial dams constructed across the Nile channels further south in the Askut and Semna area. He also cited Gottberg ${ }^{15}$ who mentioned the wide distribution of this system which he suggested reached beyond Semna for an unspecified distance towards the Third Cataract. While Vercoutter stressed the defensive character of such a system of river barriers, their chief function appears rather to have been as Willcocks suggested: an agricultural aid, which at $\mathrm{a}^{16}$ time when Egypt was maintaining garrisons in up to twelve or more places, might involve as ${ }^{17}$ many as ten thousand troops and accompanying administrative staff. A large double spur dam at Semna seems unlikely on the present archaeological evidence but this system of forming a series of terraced basins the length of Nubia and thus analogous to those existing in Egypt seems probable. The area would also form a reservoir storing up water temporarily as in the Fayum lake or even Bitter Lakes basins.

Regarding the Senusret kiosk itself, its connection with these figures becomes clear when it is remembered that at the Heb Sed celebrations the Pharaoh gave or confirmed great offerings of land, people and livestock to the temples. Do the kiosk figures therefore represent all the cultivated land in Egypt or only that belonging to the Pharaoh and temples? The kiosk was erected and dedicated at the first Sed festival, and as early as king Narmer the ruler had great numbers of animals listed in the Heb Sed scene on one of his ceremonial mace-heads. However, Ramesses III had just celebrated his Heb Sed before Papyrus Harris was compiled which would have been at or near the time of his death. The Senusret I figures as shown in comparison with those in the last papyrus record, suggest they are too substantial to be merely statistics of the royal or temple lands, and thus may represent the total of all cultivated lands in Egypt at that date. Egypt had only just recovered at the beginning of the Middle Kingdom from the effects of climatic changes resulting in extreme aridity in north Africa and elsewhere, that had lasted over the period 4200 to 4000 BP. Consequently it is unlikely that the temple endowments

13. Willcocks / Craig, 1913: 287-288.

14. Vercoutter, 1964: 219-221, pl. XI a; Vercoutter, 1966.

15. Gottberg, 1867: 21. See also Murray, 1891, 535.

16. Reisner, 1910: map pl. XV section for the Debod area.

17. Firth, 1912: pl. VI (plan of the Ginari area), pl. VIII (map of Moalla area marks an old groyne (sic) going down into the river from the east bank), pl. X (Gerf Hussein area), pl. XI also, pl. XVIII (for the Koshtamma (Ikkur) Middle Kingdom fort area). 
under Senusret I exceeded those of Rameses III by over $50 \%$, rather they may reach a total of only one third of the total aggregate at most, or perhaps half a million stjat, or a maximum of half the Ramesside endowment.

The precise laying out that is used for the field areas implies that they belonged as in later times to a form of centuration based on irrigation basins. This raises the question as to whether this system originated in Pharaonic times or later? Three of the basins listed by Willcocks ${ }^{18}$ in the Memphis (Mitrahina) sector, numbers 73-75 that include the areas Saqqara, Memphis and Giza, reach 13, 10 and $10 \mathrm{~km}$ in length, or an average of 10.5 to $11 \mathrm{~km}$ close to 1 iteru measure. Similarly a number of others far to the south in the Sohag area also average a length close to an iteru. Allowing for constant changes in these areas over recent centuries, and especially with regard to the river channel, this appears to be a remarkable example of continuity. Later administrations appear to have adhered to an effective scheme.

Until recently it was thought that the Nile in the Memphis area had for a long period flowed on the eastern side of the valley near the Helwan area as it does today, but recent geological survey findings now suggest that the river channel has moved eastward for at least $3 \mathrm{~km}$ since antiquity. This has given support to the statement of Herodotus that at least in his day, if not in the reign of Menes, the river flowed in the centre of the valley, or apparently immediately east of the Ptah temple enclosure. Unexpected confirmation of these facts is found in the extremely narrow width of lands listed in the kiosk figures for the White Wall Nome, indicating that under Senusret I these fertile lands were only 1000 cubits or $0.5 \mathrm{~km}$ wide. This fits both the geological and traditional date perfectly, and allowing that the Twenty
Second Upper Egyptian Nome centred on Atfih, stretched north for over $60 \mathrm{~km}$ to apparently meet the Heliopolitan Nome territory on the east bank of the Nile in the region opposite Memphis city, accounted for cultivated lands 6000 cubits wide or $3 \mathrm{~km}$ east to west here. The river if so simply encroached on these territories $^{19}$.

Equally remarkable is the agreement of the extremely low figures given for the extent of fertile lands in the Memphite Nome at a period at the end of the pyramid era, and the evidence now appearing that shows a disastrous falling off of food supply in Egypt at the end of the Old Kingdom, cited by Fekri Has$\operatorname{san}^{20}$ as due to world-wide adverse climatic conditions. Against this background can be seen the evidence of a belt of sand extending over a width of at least $0.5 \mathrm{~km}$ from the edge of the desert escarpment into the valley below, that remained a prominent feature until medieval times in the area from Mitrahina to Abu Roash. This would explain not only a contraction of the west bank fertile lands, but also why the stone approach constructions below the valley temples were found in some cases to have this layer over what were termed their harbour floors. This evidence may also indicate a loss of land comparable in area to that existing in this Nome under Senusret I, or since the First Dynasty up to the end of the Old Kingdom, equal to 8000 stjat [if so].

Even more dramatic evidence of the drying up of Nile flood waters is provided by the contraction of Lake Moeris in the Fayum. Earlier conclusions suggesting that the Lake had sunk from a level of at least $20 \mathrm{~m}$ above sea level, to minus $2 \mathrm{~m}$ before the end of the Old Kingdom following the establishment of the $\mathrm{V}$ united monarchy just prior to $3000 \mathrm{BC}$, have been confirmed and shown to have been even

18. Willcocks, 1889: 64.

19. Jeffreys, 1985: 48-50 and plan on pl. 2 marking the approximate location of an earlier Nile channel.

20. Hassan, 2005: 2 and especially 3-4 for recent survey work at the entrance to the Faiyum. 
more disastrous. What was a natural process of water decline has also been shown to have been on one occasion reversed by artificial interference by man. The views of Ball and other writers who considered that the Twelfth Dynasty kings beginning with Amenemhat I, and certainly later under Amenemhat III, were responsible for restoring the lake to something like its old levels ${ }^{21}$ are also to be taken into account. The usual explanation is that the entrance channel to the Fayum having become blocked or partly so, hydraulic works were undertaken to clear it. In this context the function of the great Qusheisha dyke running across the flood plain in the Nile valley near Lisht, as well as the north dyke at Lahun at the entrance to the Fayum entrance channel, may have retained large quantities of inundation water and diverted a considerable amount into the Fayum entrance channel. The former barrier is located near the pyramids of Amenemhat I and Senusret I, and the latter at the pyramid city of Senusret I, a Pharaoh associated with Nubian flood height inscriptions.

In this context the Nubian flood heights recorded at Semna under Amenemhat III and the earlier Thirteenth Dynasty kings are highly significant, showing over a period of about seventy years heights averaging up to $8 \mathrm{~m}$ above modern levels prior to the creation of the reservoir created by the Aswan dam in the 1960 period. Such enormous flood waters while partly natural also suggest the effects of the Nubian stone spur dams, and would account for much higher levels than those recorded between Abu and Per Hapi on the Senusret kiosk. Combined with the dykes cited above the effect would have created the higher water levels in the Nile valley needed to refill the newly restored Lake Moeris to around $+15 \mathrm{~m}$ under Senusret I and it would seem nearly $+18 \mathrm{~m}$ under Amenemhat III when the paving of his colossal statue courts at Biahmu was laid down. These levels cannot have been higher until later or the courts would have been flooded and their walls half submerged as Herodotus saw.

The views of Fekri Hassan should be seen against this background as confirming that geological evidence of a major, if not total, drying up in the Fayum depression and a great loss of cultivated land throughout Egypt and especially in the Delta. While the kiosk figures do not indicate any possible reclaimed land in the Lake Moeris area around Shedet, they do show that in both the Nile valley and Delta there may have been a considerable decline from the cultivated land area during the Old Kingdom up to the earlier Fifth Dynasty.

How much earlier than the Twelfth Dynasty the basin irrigation system can be traced is at present largely dependent on textual evidence. During the five thousand year period since the First Dynasty, the silt deposits in both valley and Delta would, on an average rate of $10 \mathrm{~cm}$ a century, have reached to about $5 \mathrm{~m}$ above their original level. This would have covered not only all the field surfaces but any existing cross dykes defining the basins, which if averaging about $3 \frac{1}{2} \mathrm{~m}$ in height as in modern times would be invisible if not totally obliterated. Willcocks pointed out that much damage was done to the Delta dyke system under Muhammad Ali at the time of the creation of the Barrage to the north of Cairo and new irrigation system no longer using dykes ${ }^{22}$. But there are indications of an earlier basin scheme in the Palermo Stone Annals, which contain a series of Nile heights recorded from at least as early as the second or more probably third First Dynasty king ${ }^{23}$. This indicates they were

21. Ginter / Heflik / Kozlowski / Sliwa, 1980: 154-158.

22. Willcocks, 1889: 89-90.

23. Wilkinson, 2000, gives the latest comprehensive analysis of this monument, but does not discuss the implications of the Nile height figures. He does, however, give a helpful picture of the period in which they were compiled. 
already being recorded within a period of sixty years from the beginning of this Dynasty or possibly from his first Pharaoh's reign. It has often been noted that they show a marked decline from just over 5 cubits $(2.60 \mathrm{~m})$ under king Nineter in the Second Dynasty. This figure remained roughly constant until the last surviving entry under king Neferirkare' in the earlier Fifth Dynasty. What happened in the Sixth Dynasty and after is missing but as shown geological evidence indicates a drastic falling off in water levels.

These later Palermo Stone levels may usefully be compared with the Senusret I general levels for the valley between Abu and Per Hapi or 3 cubits 3 palms 3 fingers. This suggests that the flood water level had returned to approximately the level it reached under the Fifth Dynasty and that the Annals relate to Upper Egypt. It has been suggested that the stone monument itself was set up in one of the Fifth Dynasty temples at Abu Gurob, and or least in the Memphis city area ${ }^{24}$. These figures logically would be taken from a central observation point, and a Nilometer sited in the Athar en Nabi area at Cairo would be nearly opposite to Memphis itself and the most probable location rather than $\mathrm{Abu}$ or any other position.

In conclusion the question as to when this unified irrigation system was first conceived may tentatively be answered by examining the following clues. The first steps may have been taken in the late Protodynastic period by one or more of the kingdoms in the Nile valley or Delta, but a unified basin system like a common calendar and Sothic dating requires a unified kingdom. Hence perhaps it was initiated by Menes himself either combining some small existing projects in different areas, or laying out a completely new system throughout the Nile valley. The tradition recounted by the priests to Herodotus relating the foundation of the White Wall settlement or precursor of Men-nefer (Memphis), does not say that Menes diverted the Nile to do so, as often stated, only that the river had previously flowed freely all over the valley here in its natural state, and the flood waters reached the western edge of the plain below the rock escarpment as at Saqqara. It adds that these waters were now confined to a fixed channel within its existing bed $^{25}$. Not surprisingly this was taken by the Greek traveller to be near to where it ran in his day, hence towards the valley centre.

This statement is entirely logical as the first major undertaking in creating a unified irrigation system would involve embanking the Nile throughout the whole valley between Aswan and Cairo, and then continuing the work across the Delta along one or more of its branches as far as the coast. A series of dykes constructed at right angles to the river banks would then be added to form a series of basins at regular intervals on one or both sides of the river channel, in the valley and later along the Delta branches.

The Twelfth Dynasty Pharaohs perfected and possibly enlarged the system, and the figures in Senusret I's chapel help to confirm other textual, archaeological and geological evidence as to the working of this gigantic undertaking. Beginning probably under Amenemhat I and continuing for two centuries until the reign of Amenemhat III, the system was apparently supplemented by gigantic hydraulic works, intended to restore if not increase the natural water supply as it existed under the Old Kingdom in its heyday. These involved works on and at the entrance to the

24. Gardiner, 1964: 62-63, considered that the original stone slab's entries ended under King Niuserre' rather than Neferirkare' the last surviving named king in the entry sequence. This dating if so implies a possible location in one of the sun temple at Abu Gurob near Memphis. Wilkinson more cautiously opts for the general area of the Ptah temple there.

25. Hdt II, 99. 
Fayum intended to restore and later increase the levels of Lake Moeris, possibly the creation or restoration of a canal along the eastern section of Wadi Tumilat, that turned Lake Kem Wer (Timsah) and the Bitter Lakes into an additional if smaller Nile water reservoir, and most important of all, the creation of other basins and thus fertile ground in the Nubian valley by the introduction of stone spur partial dams.

This evidence shows that in the reign of Senusret I Egypt possessed an irrigation system of unparalleled magnitude extending for a distance of 147 iteru or $1543 \mathrm{~km}$ over a river channel about 190 iteru or $1995 \mathrm{~km}$ long between Semna South fort and Pehu Behdet or say $2000 \mathrm{~km}$ to the sea.

On the basis of modern basins there must have been at least $1000 \mathrm{~km}$ of earth dykes in addition to several thousand $\mathrm{km}$ of river banks along the valley and Delta branches. These required constant earth moving and working to maintain and renew, involving the use of millions of cubic metres of material.

As shown earlier the total area of the Lower Egyptian cultivated land demonstrated in the figures in Senusret I's chapel was around 900000 stjat or 246150 ha. Their basins lay in a triangle measuring about 20 iteru on each side, equal to the distance from Per Hapi to Pehu Behdet. When flooded in the inunda- tion season these must have resembled an inland sea or vast lake. Perhaps this explains the greatly exaggerated circuit Herodotus gave to Lake Moeris. Instead of its true periphery of about $210 \mathrm{~km}$ at a surface level of $+15-16 \mathrm{~m}$ above sea level under the earlier Twelfth Dynasty, he gave it as three times as much, 60 schoeni or the Greek equivalent of 60 iteru, roughly $630 \mathrm{~km}$. His statement that this was equal to the coast of Egypt would in fact be correct if this meant only that which lay along the north side of the basin triangle circuit ${ }^{26}$.

A further link between the two areas may have been in the use of Lake Moeris as a storage reservoir and possible source of irrigation in times of Low Niles. At the surface level given above it had an area of approximately 1600 $\mathrm{km}^{2}$ as opposed to the $2461 \mathrm{~km}^{2}$ of the Lower Egypt lands. On this ratio of two to three, to flood the Delta lands to a height of $1 \mathrm{~m}$ in times of water shortage would require $1.5 \mathrm{~m}$ drawn off the waters of Lake Moeris. In fact the Senusret I figures give only around $90 \mathrm{~cm}$ for the average water level on the Delta fields, hence to supply part of this amount to make up any annual deficit would be well within the capacities of the great reservoir's normal content.

In conclusion it may be said that the ancient Egyptian irrigation system was a far greater wonder than any other wonder in Pharaonic times or for that matter in the ancient world list. 


\section{BibliograPhY}

FIRTH, C.M.

1912 Archaeological Survey of Nubia Report 1908-1909, vol II. Cairo.

GARDINER, A.H.

1964 Egypt of the Pharaohs. Oxford.

Ginter, B.; Heflik, W.; Kozlowski, J.K.; Sliwa, J.

1980 "Excavations in the Region of Qasr elSagha", MDAIK 36, 105-169.

Gottberg, E. De

1867 Des cataracts de Nil. Paris.

Guides Bleus

1950 Égypte. Paris.

HASSAN, F. A.

2005 "A Rivers Runs Through Egypt: Nile Floods and Civilization". GeotimesApril 2005, http://www.geotimes.org/ apr05/feature_NileFloods.html.

JEFFREYS, D.G.

1985 The Survey of Memphis I. The archaeological report. London.

LACAU, P.; ChÉVRIER, H.

1956 Une Chapelle de Sésostris I er à Karnak. Textes. Le Caire.

1969 Une Chapelle de Sésostris I er à Karnak. Planches. Le Caire.

Montet, P.

1961 Géographie de l'Égypte ancienne. Paris.

Murray, J

1880 A Handbook for Travellers in Lower and Upper Egypt, including descriptions of the course of the Nile through Egypt and Nubia. London.

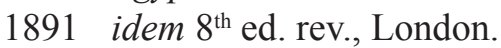

REISNER, G.A.

1910 Archaeological Survey of Nubia Report 1908-1909, vol I, Cairo.

UPHILL, E.P.

1998 The Boundaries and Orientation of Akhetaten, in Proceedings of the Seventh International Congress of Egyptologists, Cambridge, 3-9 September 1995. OLA 82, Leuven, 1191-95.

VerCOUTTER, J.

1964 "Excavations at Mirgissa, I (OctoberDecember 1962)", Kush 12, 57-62.

1966 "Semna South Fort and the Records of Nile Levels at Kumma", Kush 14, 114-60.

WILKINSON, T.A.H.

2000 Royal Annals of Ancient Egypt: The Palermo Stone and its associated fragments. London.

WiLLCOCKS, W.

1889 Egyptian Irrigation. London.

Willcocks, W.; Craig, J. I.

1913 Egyptian Irrigation. Third Revised Edition. London.

WILSON, J.A.

1957 The Culture of Ancient Egypt. Chicago. 


\section{Juan Antonio Belmonte}

Instituto de Astrofísica de Canarias

Vía Láctea $\mathrm{S} / \mathrm{N}$

38200 La Laguna, Tenerife - Islas Canarias

España

$$
\text { jba@iac.es }
$$

\section{Marcelo Campagno}

Instituto Multidisciplinario de Historia y Ciencias Humanas

Departamento de Egiptología

Saavedra $15,5^{\circ}$ piso

C1083ACA Buenos Aires

Argentina

mcampagno@fibertel.com.ar

\section{Lucía Elena Díaz-Iglesias Llanos}

Dpto. de Prehistoria, Antropología e Historia Antigua

Facultad de Geografía e Historia - Campus de Guajara

38071 Universidad de La Laguna

Tenerife - Islas Canarias

España

luch68@hotmail.com

\section{Magdi Fekri}

Faculty of Tourism

Minufiya University

El-Sadat City

Egypt

per-ankh@hotmail.com

\section{Cristina Pino Fernández}

cristinapino@telefonica.net 


\section{Mosalam Shaltout}

Helwan Observatory

Helwan, Cairo

Egypt

mosalamshaltout@hotmail.com

\section{Eric P. Uphill}

Institute of Archaeology

University of London

31-34 Gordon Square

London WC1H OPY

United Kingdom

\section{Marie-Paule Vanlathem}

Association Égyptologique Reine Élisabeth Musées Royaux d'Art et d'Histoire

Parc du Cinquantenaire 10

B-1000 Bruxelles

Belgique

mariepaule.vanlathem@belgacom.net 


\section{Trabajos de Egiptología}

\section{Papers on Ancient Egypt}

P

Número 4 2005 


\title{
Consejo Editorial
}

\author{
Miguel Á. Molinero Polo \\ Universidad de La Laguna \\ Antonio Pérez Largacha \\ Universidad de Castilla-La Mancha \\ José-R. Pérez-Accino \\ Birkbeck, Universidad de Londres \\ Covadonga Sevilla Cueva \\ Universidad Autónoma de Madrid
}

\section{Comité Científico}

Josep Cervelló i Autuori

Aula Aegyptiaca, Barcelona

Ma José López Grande

Universidad Autónoma de Madrid

Josep Padró i Parcerisa

Universitat de Barcelona

$\mathrm{M}^{\mathrm{a}}$ Carmen Pérez Die

Museo Arqueológico Nacional, Madrid

Ester Pons Mellado

Museo Arqueológico Nacional, Madrid

José M. Serrano Delgado

Universidad de Sevilla

\section{Colaboradores Editoriales}

Linda Steynor

English editorial assistant

Hervé Mouriacoux

Assistant editoriale pour langue française 
Juan Antonio Belmonte, Mosalam Shaltout, Magdi Fekri

Astronomy and landscape in Ancient Egypt:

Challenging the enigma of the minor step pyramids

\section{Marcelo Campagno}

Two observations on the tales of The contendings of Horus and Seth and Truth and Falsehood

\section{Lucía Elena Díaz-Iglesias Llanos}

Commentary on Heracleopolis Magna from the theological perspective (I):

The image of the local lakes in the vignette of chapter 17 of the Book of the Dead

Cristina Pino Fernández

Prince Ahmose Sapair again

Eric P. Uphill

Irrigation basins and cultivated land under the Twelfth Dynasty

\section{Marie-Paule Vanlathem}

Cléopâtre dans le miroir de la peinture du XIXe siècle 
Trabajos de Egiptología está producida por Isfet. Egiptología e Historia.

c/ Blanco $1,2^{\circ}$

38400 Puerto de la Cruz

Tenerife - Islas Canarias

España

Maquetación: Ignacio Cases

(C) Autores de los artículos aparecidos

y Consejo Editorial de Trabajos de Egiptología - Papers on ancient Egypt

Depósito legal:

ISSN 1695-4750

Impresión: 